\title{
OPTIMIZATION OF POWER CONSUMPTION OF BELT CONVEYER SYSTEM BY REPLACING ADJUSTABLE NON-CONTACT TYPE INTERNAL SCRAPER
}

\author{
A.L.N.Arun kumar ${ }^{1}$, S.MD.Jameel basha ${ }^{2}$, Dr. M. Sreenivasulu ${ }^{3}$ \\ ${ }^{I}$ Assistant Professor, Mechanical Engineering, C.V.R College Of Engineering, Andhra pradesh, India \\ ${ }^{2}$ Assistant Professor, Mechanical Engineering, N.I.S.T, Andhra pradesh, India \\ ${ }^{3}$ Professor, Mechanical Engineering, N.B.K.R.I.S.T, Andhra pradesh, India
}

\begin{abstract}
The Conveyer System finds its Application where manual material transfer fails. Conveyor system is a common piece of mechanical handling equipment that moves materials from one location to another. Belt Conveyor systems are used widespread across a range of industries due to the numerous benefits they provide. Though these conveyors have numerous advantages they also require huge amount of power to drive belts. As the result of increased fuel prices in global markets and scarce of fuels electricity tariff is increasing tremendously. By reducing drive power requirement we can save huge amounts of money as well as reduce green house gas emissions. The project involves analysis of changes in power consumption by replacing the contact type internal scraper with Adjustable Type Non-contact internal scraper.
\end{abstract}

Key Words:, scarce, emissions, scraper, etc...

\section{INTRODUCTION}

The first conveyor belts were developed in the late 18th century, with most sources pointing at the year 1795 as the first instance of a conveyor. Consisting of leather belts running over wooden beds, they were short and were powered with hand cranks and a series of pulleys.

Changes in technology are certain to keep the industry in motion as users look for faster throughput, diverted sorting and use of wireless technologies. Primitive conveyor belts were used since the 19th century. In 1892, Thomas Robins began a series of inventions which led to the development of a conveyor belt used for carrying coal, ores and other products. In 1901, Sandvik invented and started the production of steel conveyor belts. In 1905 Richard Sutcliffe invented the first conveyor belts for use in coal mines which revolutionized the mining industry. In 1913 Henry Ford introduced conveyor-belt assembly lines at Ford Motor Compsnies's Highland Park, Michigan factory. In 1972, the French society REI created in New Caledonia the then longest straight-belt conveyor in the world, at a length of $13.8 \mathrm{~km}$.

\subsection{Need of Conveyor Systems}

With the dawn of the 20th century came the industrial revolution as well as much great advancement in conveyor technology. In 1901, the first steel belt was invented in Sweden. They can be installed almost anywhere, and are much safer than using a forklift or other machine to move materials. They can move loads of all shapes, sizes and weights. Also, have many advanced safety features that help prevent accidents. There are a variety of options available for running conveying systems, including the hydraulic, mechanical and fully automated systems, which are equipped to fit individual needs.

\subsection{Majorly Used Conveying Systems To Transfer}

Coal:

Apart from the belt conveyer systems there are few other conveyer systems are use for bulk material transport like coal, the following are majorly used conveyer systems for coal.

\subsubsection{Screw conveyor}

A screw conveyor or auger conveyor is a mechanism that uses a rotating helical screw blade, called a "flighting", usually within a tube, to move liquid or granular materials. They are used in many bulk handling industries. The first type of screw conveyor was the Archimedes' screw, used since ancient times to pump irrigation water

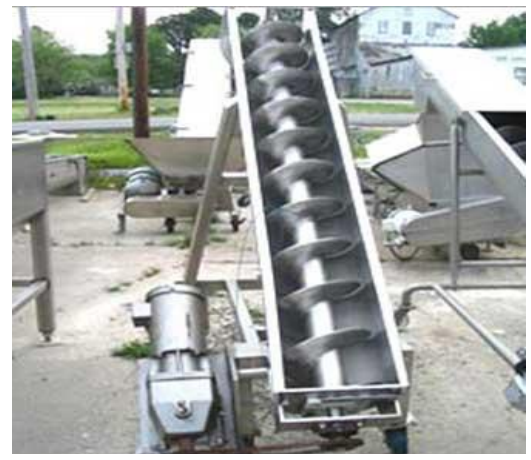

Figure - 1 : Screw Conveyer System 


\subsubsection{Bucket Conveyor}

A bucket conveyor is a mechanism for hauling flowable bulk materials (most often grain or fertilizer) vertically/inclined. A bucket conveyor can elevate a variety of bulk materials from light to heavy and from fine to large lumps. A centrifugal discharge conveyor may be vertical or inclined. Vertical conveyors depend entirely on the action of centrifugal force to get the material into the discharge chute and must be run at speeds relatively high.

\section{It consists of:}

1. Buckets to contain the material;

2. A belt to carry the buckets and transmit the pull;

3. Means to drive the belt;

4. Accessories for loading the buckets or picking up the material, for receiving the discharged material, for maintaining the belt tension and for enclosing and protecting the conveyor.

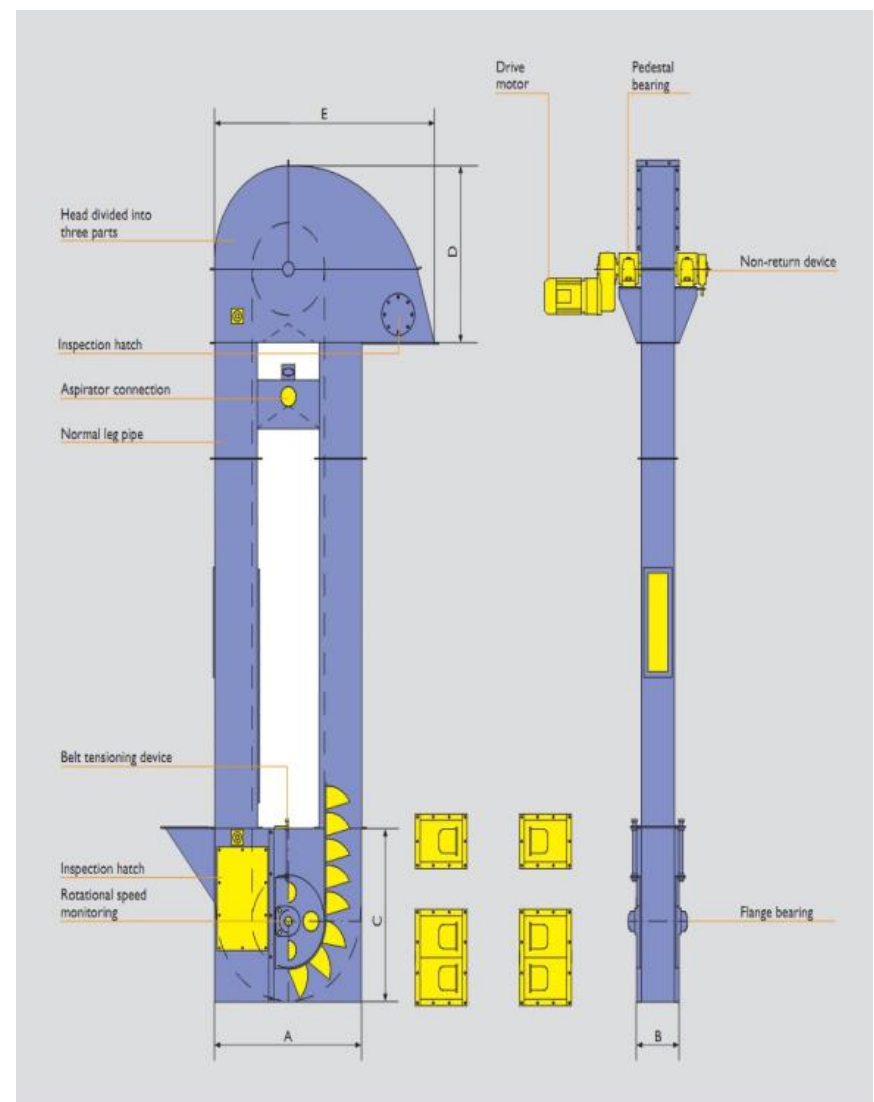

Figure - 2: Schematic diagram of Bucket Conveyer System

\section{LITERATURE SURVEY}

Some journal papers were selectively studied for the various parameters regarding the power calculations which are having direct relevance with my work. And most of the design data has been taken from the SEW Project Pvt.Ltd and power calculations related data and formulae were studied in IS standard book along with CEMA book for belt conveyer systems

\subsection{Design Considerations of Major Components of Belt Conveyor System}

\subsubsection{Conveyor Frame Structure:}

The conveyor structure shall consist of independent prefabricated tables. The length shall be 5 to $6 \mathrm{~m}$ Stringers shall be channels and the channel size for stringers shall be minimum $200 \mathrm{~mm}$. Self cleaning V type deck plates shall be provided under the loading points; extending $1.0 \mathrm{~m}$ before and after the end of the loading skirts and above the Vplows protecting the return pulleys. For the stockyard conveyors the deck plate shall be provided for the entire travel length of the stacker-reclaimer.

\subsubsection{Take-Up Units:}

The take-up travel shall be $2.5 \%$ (Minimum) of the centre of the drive pulley to centre of tail pulley distance for Nylon belting and $1.5 \%$ (Minimum) of centre of the drive pulley to centre of tail pulley distance for EP belting.

\subsubsection{Vertical Take-up Units:}

Vertical gravity take-up units shall have $0.5-0.75 \mathrm{~m}$ sand box provided under the counter weight at ground/floor level. The area below the counter weight shall be guarded to a height of $2.5 \mathrm{~m}$ above any access level.

\subsubsection{Horizontal Take-up Units:}

The pulley slide frame shall be self-cleaning type. The pulley slide carriage shall be equipped with Vee type wheels attached to shaft running on guide rails

\subsubsection{Idler Assembly:}

Carrying idlers for all belts shall be three roll garland type with articulated joints having freedom of movement in both vertical and horizontal directions for all conveyors. Carrying idlers shall have 45 degrees trough angle. Idler rolls shall be made of ERW tube

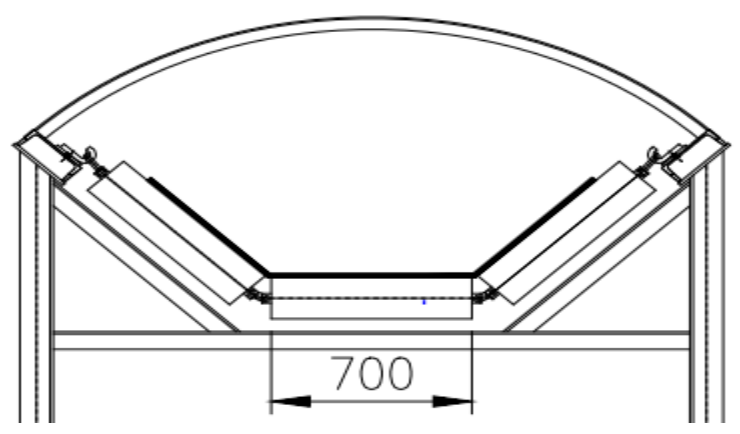

Fig - 3. Garland Type Idlers 


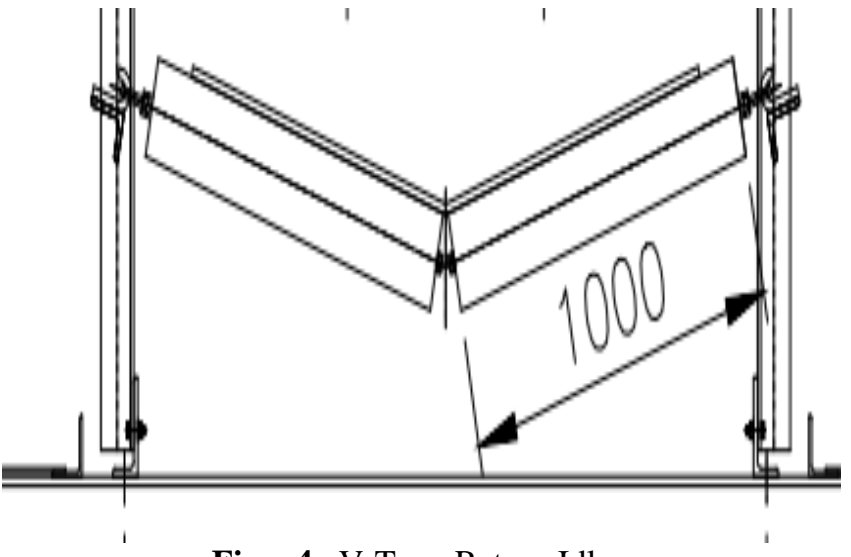

Fig - 4 . V-Type Return Idler

\subsubsection{Pulleys:}

Pulleys shall be made of welded steel and stress relieved, before machining. Pulley shell joints shall be $100 \%$ radio graphically tested. All pulleys shall be straight faced

\subsubsection{Belting:}

Belting for conveyors shall be Nylon-Nylon/ EP type and suitable for heavy duty application. It shall be able to with stand the tensions and support the load. The rated maximum allowable working tension shall exceed the calculated maximum running tension by atleast $15 \%$. Ratio of breaking strength to working tension shall be 9 for Nylon-Nylon belting and 7 for steel cord belting

\section{MODELLING AND ANALASYS OF}

\section{INTERNAL SCRAPER}

\subsection{Introduction To CATIA V5:}

CATIA Version 5 uses the Sketcher workbench as its principal method to create profiles. These profiles can be constrained using many different types of constraints. The first objective of the course is to learn to use the Sketcher and constrain your profiles to the desired specifications. If you have used the Dynamic Sketcher from CATIA Version 4 , this will look very similar. Otherwise it is a new environment and it can be frustrating at first, especially if you already know CATIA Version 4. However, in time you will find that it is a very powerful method for creating profiles, and is easy to use.

\subsection{Major Tools Used In Modeling Of Internal}

\section{Scraper:}

\subsubsection{PAD:}

The application of this feature is to add the material of a cross section in the both positive and negative normal direction.

\subsubsection{HOLE:}

The application of this feature is to remove the material of a cross section in the $b$ normal direction. The material will be removed according to the shape of the cross-section or profile drawn on the object.

\subsubsection{PATTERN:}

The application of this feature is to create similar crosssections at specified position and in specified place according to the requirement. The patterns are various types depending upon the requirement, those are rectangular pattern and circular pattern etc.

\subsubsection{ROTATE:}

Rotate is one of the most important features in sketcher workbench this facilitates easy viewing of the object in all directions around 360 degrees.

\subsubsection{FIT ALL IN:}

By using this tool we can bring the complete object into the fit to screen position in order to have clear vision on the object

\subsubsection{PAN:}

PAN is used to move the object along with the cursor position, this is useful to move the parts from one position to the other position.

\subsection{Modelling Of Various Parts Of Internal}

\section{Scraper.}

The following are the various parts of internal scraper arrangement of belt conveyer system.
1. V-PLOUGH
2. FRONT PLOUGH
3. BACK PLOUGH
4. ARM
5. WELDED CROSS MEMBER
6. BOLT AND NUT

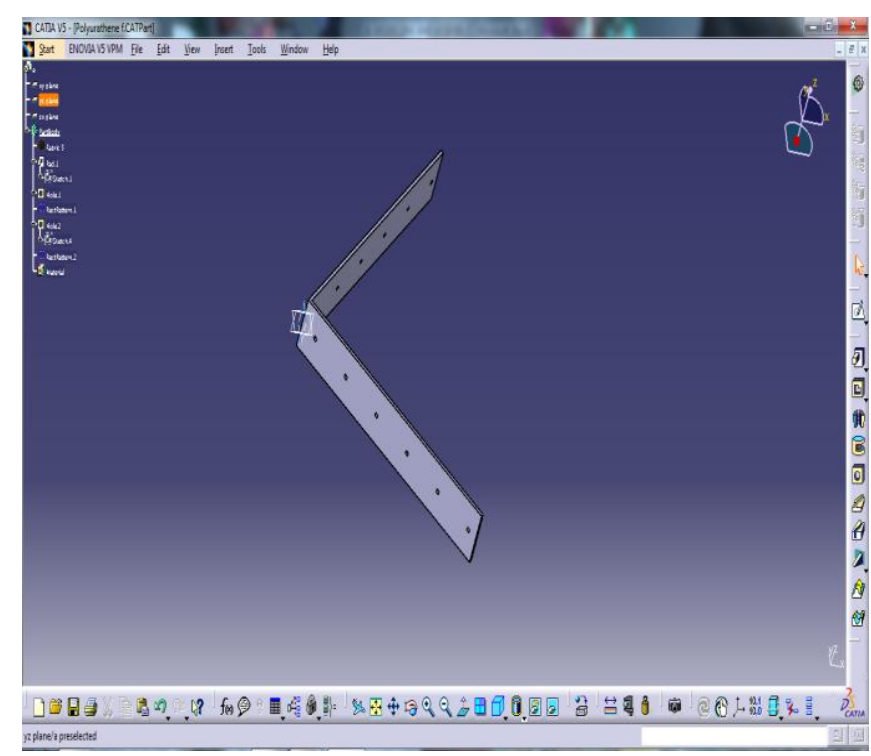

FIG - 5: PART MODEL OF VPLOUGH 


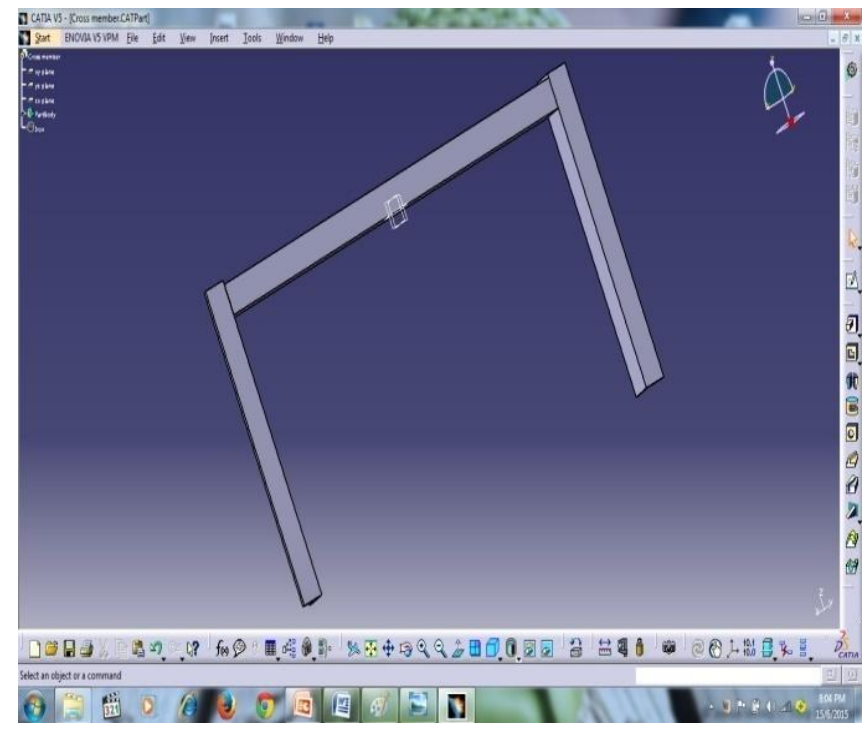

FIG - 6: WELDED CROSS MEMBER PART MODELING

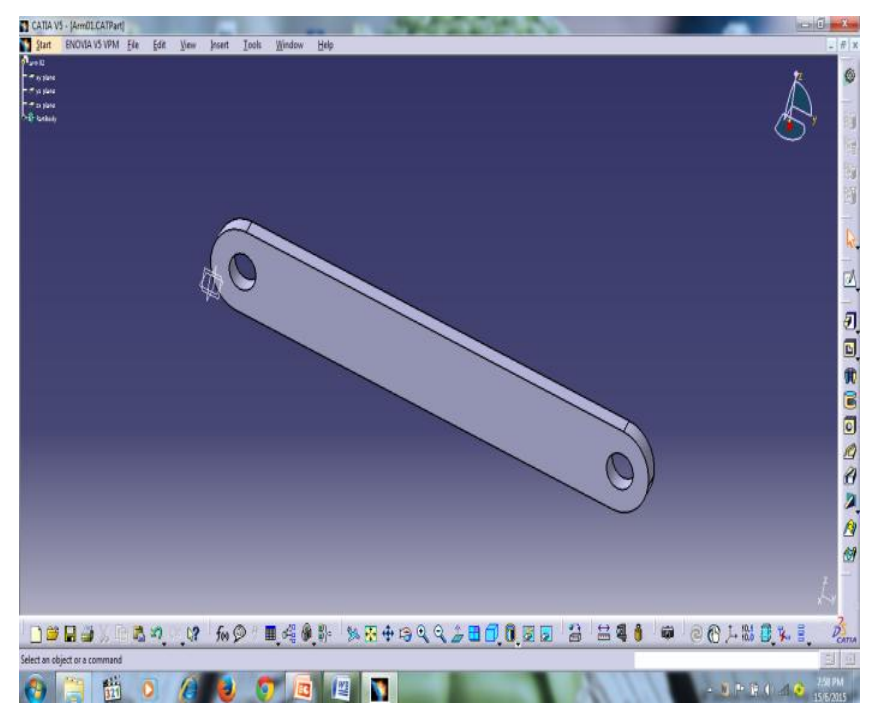

FIG - 7: ARM PART MODELING

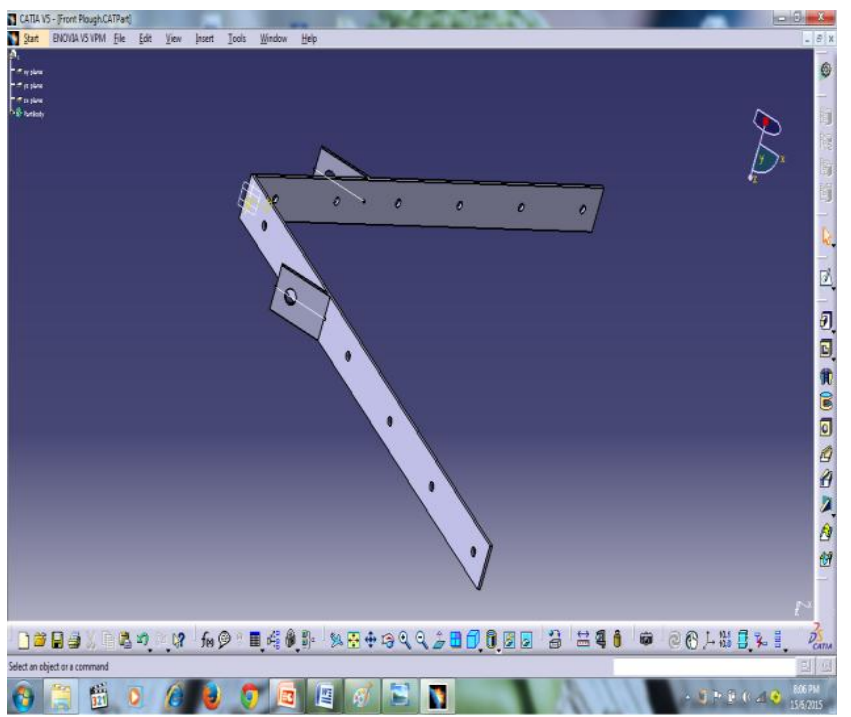

FIG 8: PART MODELING OF FRONT PLOUGH OF VPLOUGH

\subsubsection{Assembly of Internal Scraper:}

All the parts created in part modeling workbench are assembled in ASSEMBLY WORKBENCH. The following figure shows the assembled component of a Internal Scraper arrangement designed for the Belt Conveyer System for Coal Handling

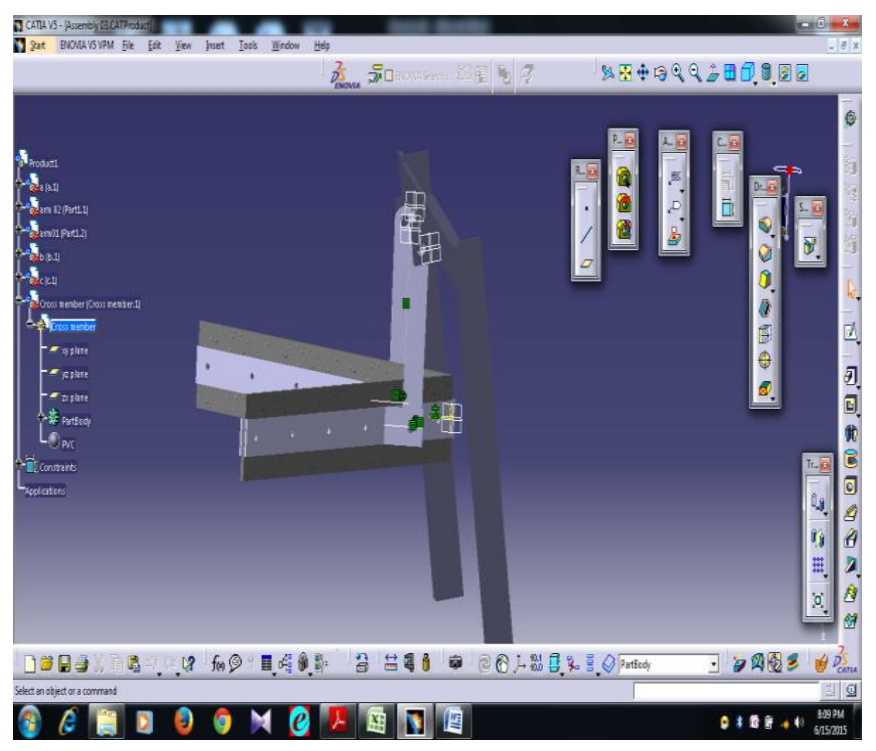

FIG - 9 : ASSEMBLY OF INTERNAL SCRAPER ARRANGEMENT

\section{ANALYSIS OF INTERNAL SCRAPER WITH} RUBBER MATERIAL USING CATIA V5:

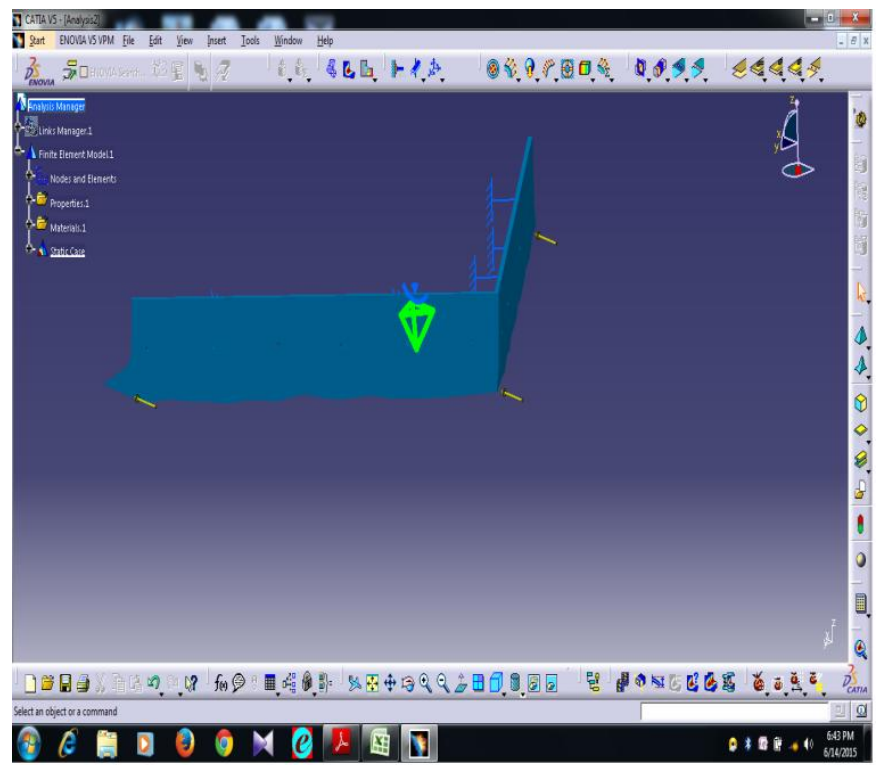

FIG 10: DEFLECTION OF V-PLOUGH WITH RUBBER MATERIAL 


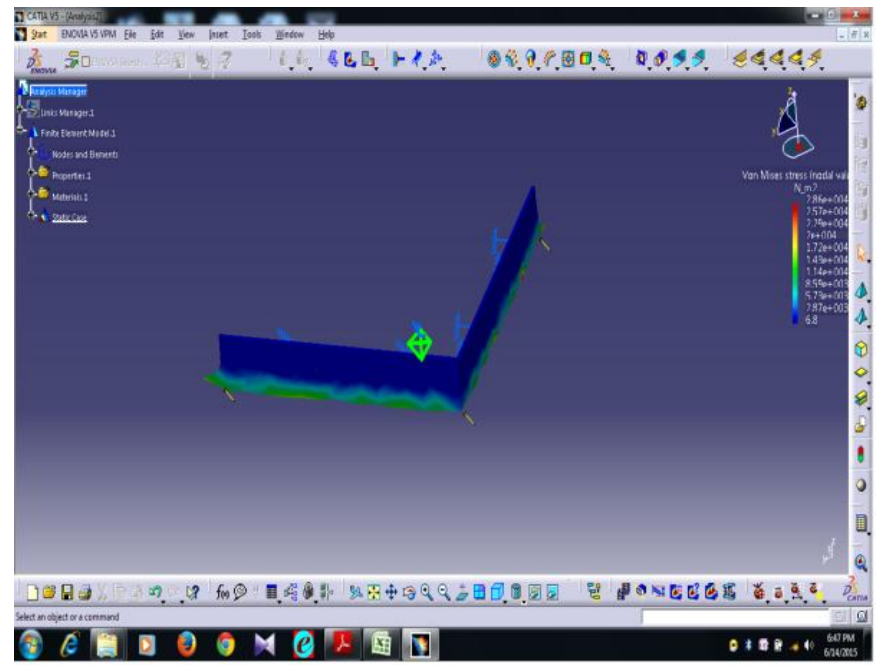

FIG - 11: STRESS CONCENTRATION REGIONS OF VPLOUGH WITH RUBBER

\subsection{ANALYSIS OF V-PLOUGH WITH}

\section{POLYURETHANE MATERIAL :}

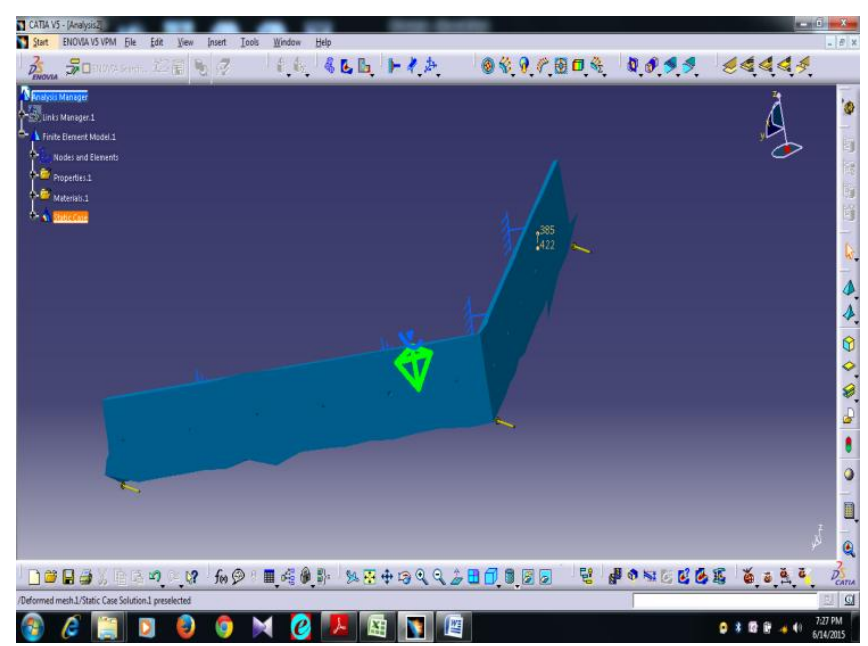

FIG - 12: DEFLECTION OF V-PLOUGH WITH "PU" MATERIAL

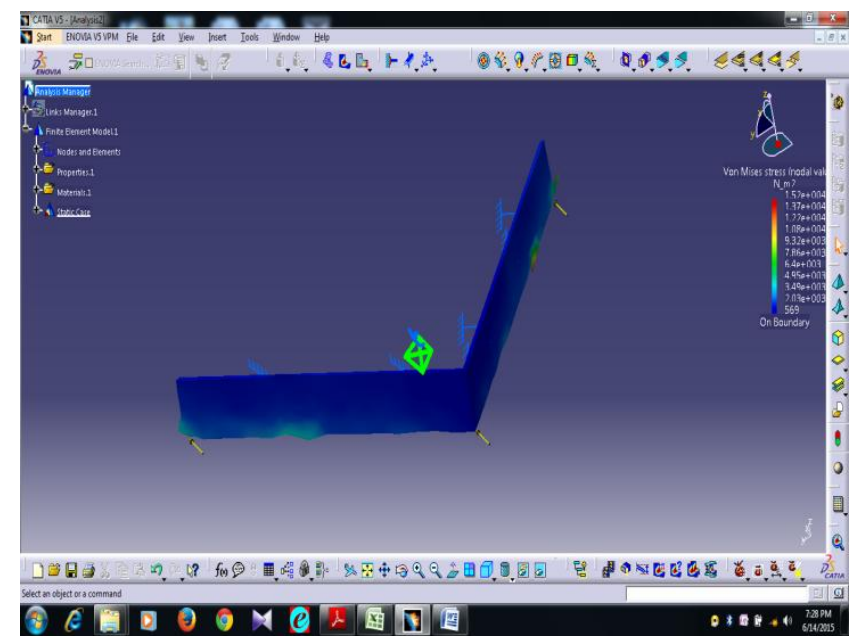

FIG - 13 : STRESS CONCENTRATION REGIONS OF VPLOUGH WITH PU MATERIAL

\subsection{ANALYSIS OF V-PLOUGH WITH PVC}

\section{MATERIAL :}

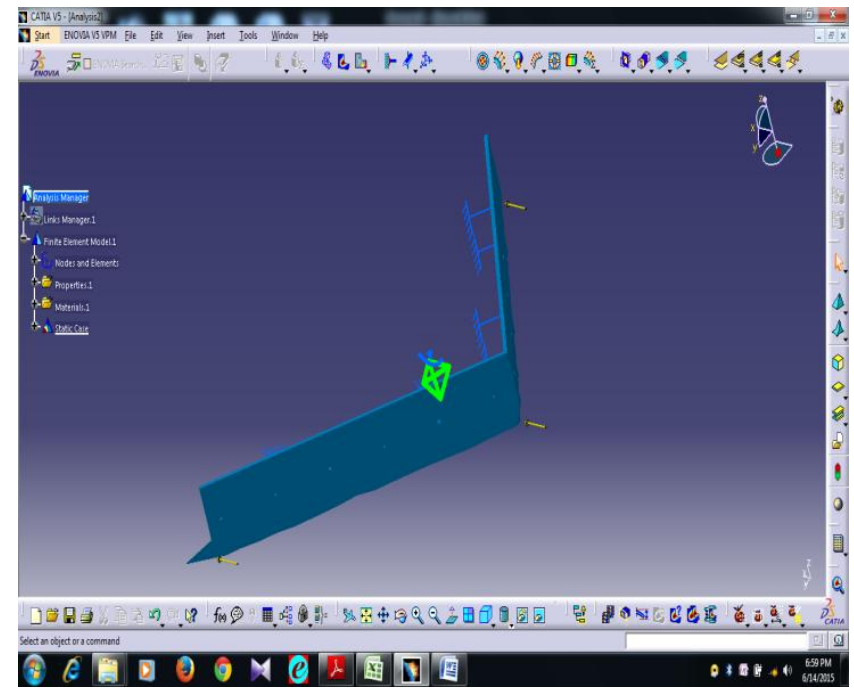

FIG - 14 : DEFLECTION OF V-PLOUGH WITH PVC

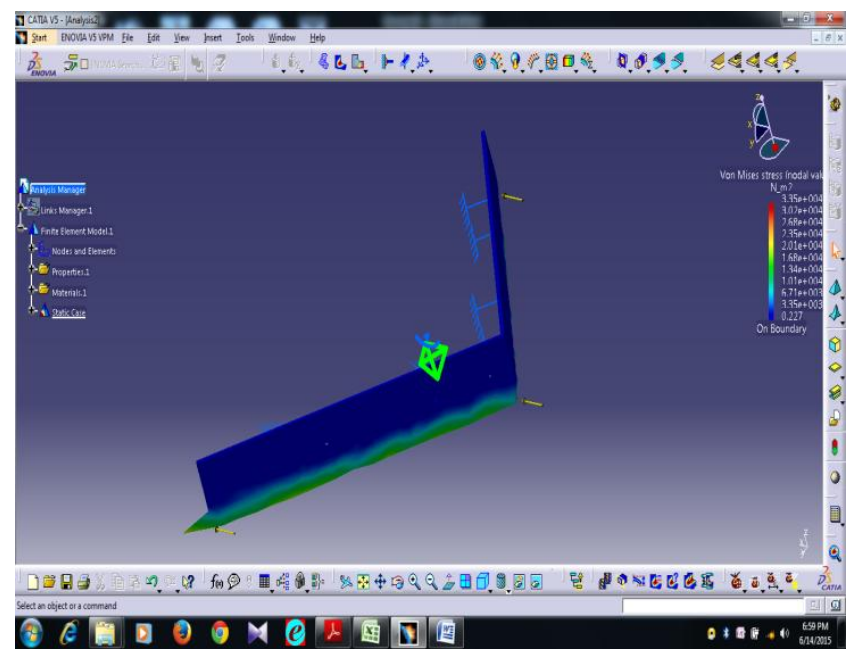

FIG - 15: STRESS CONCENTRATION REGIONS OF VPLOUGH WITH PVC

\section{RESULTS AND DISCUSSION}

As the Scraper always in-contact with the moving belt which is continuously moving at a rated speed may carry some dust and coal particles which are less than the lump size. Hence the scraper has to remove the unwanted particles present on the non-carrying side of the belt in order to avoid the damage of the pulleys as well the Idlers(both carrying and return). So the main purpose of a scraper is to remove unwanted particles and it has to sustain the shock-loads due to the belt. Hence the material which is used for the VPlough should be capable to deform up to certain limits and it should possess the minimum stress concentration limits.

The following Images Shows the Stress Concentrations on a Scraper V-Plough of Internal Scraper Arrangement. 


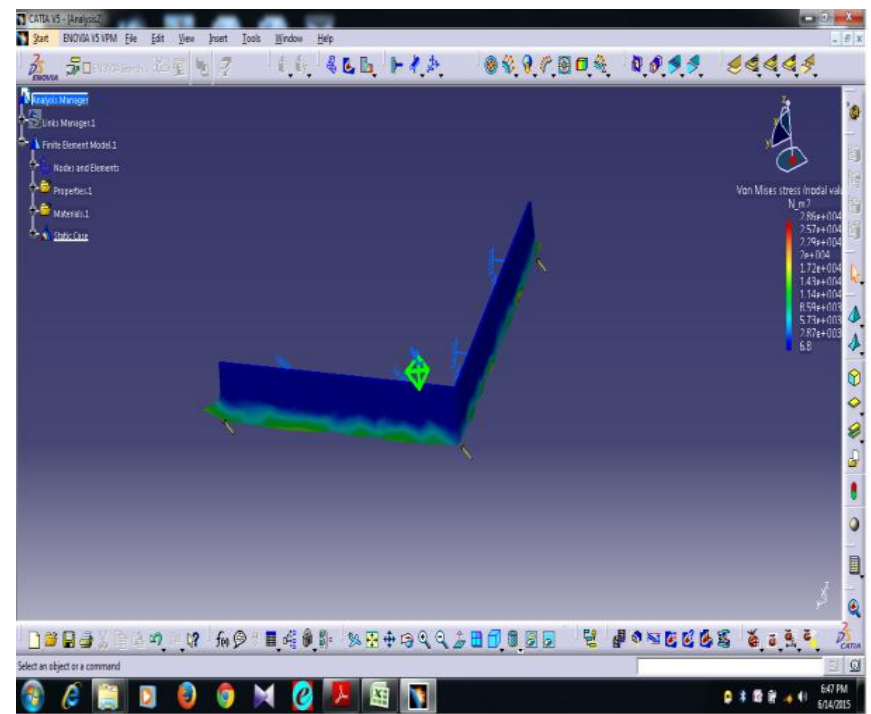

Fig - 16 : STRESS CONCENTRATION REGIONS OF V-PLOUGH WITH RUBBER MATERIAL

From the above diagram it has been observed that as the rubber material is used for the $\mathrm{V}$-Plough it is deforming continuously and is not capable of sustaining huge shock loads also the stress concentration is below the range and is not uniformly distributing. Hence the Rubber material is not recommended for V-Plough.

The following is the deflection of V-Plough with PVC as a material. When compared with the rubber material PVC is providing very low deflection but the elasticity of $\mathrm{PVC}$ is comparatively less than the rubber material. Hence the low elasticity material may failure quickly than the high elastic materials. The main motto of any design is to have longer life time with minimal maintenance costs.

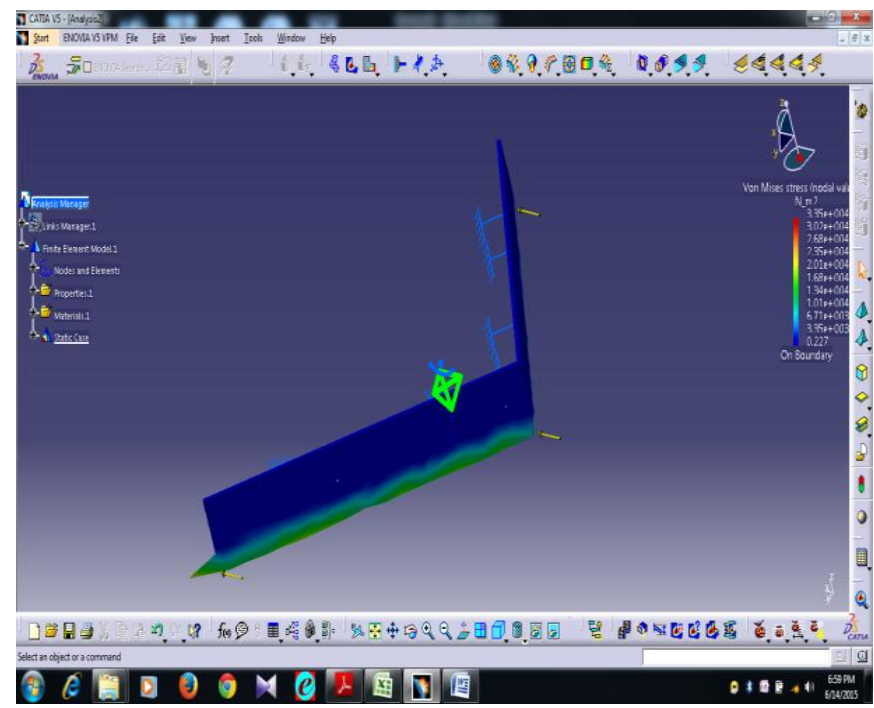

Fig - 17 : STRESS CONCENTRATION REGIONS OF V-PLOUGH WITH PVC MATERIAL

The above figure shows the static analysis of a V-Plough with PVC material. The stress concentration of a plough is in the range of loads applied on the V-Plough. Hence the PVC material is better than the Rubber material.
From the above discussion it is clear that the material used for the V-Plough should have moderate elasticity compared to both Rubber and PVC. So the deflection and static analysis are done for V-Plough with polyurethane as base material because the properties of a poly urethane rubber are in $\mathrm{b} / \mathrm{n}$ the Rubber and PVC.

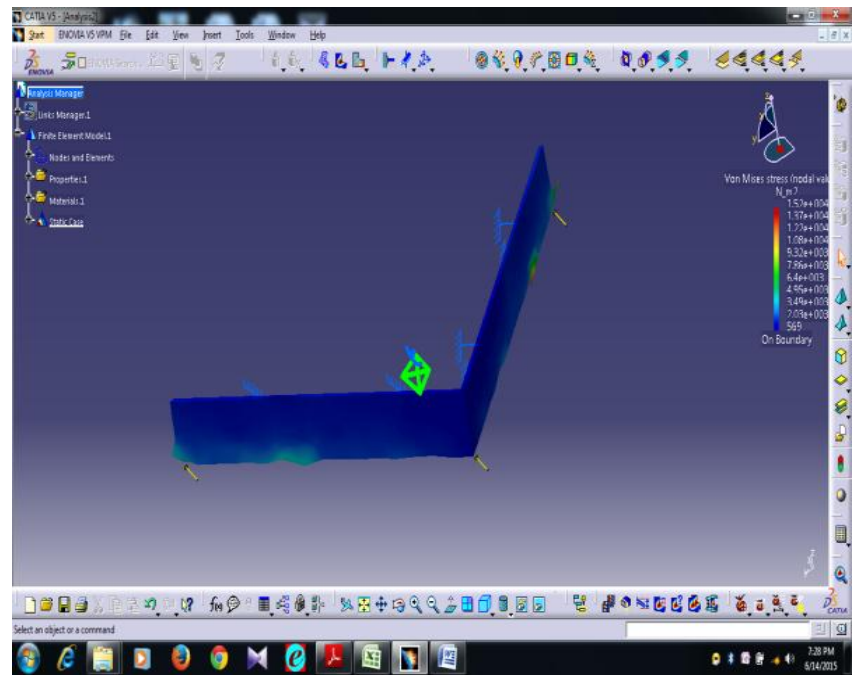

Fig - 18 : STRESS CONCENTRATION REGIONS OF V-PLOUGH WITH POLYURETHANE RUBBER

The above image shows the stress concentrated regions of a V-Plough with Polyurethane Rubber and it is observed that the stress regions are exactly in between the limits of shock loads due to belt and coal of maximum than lump size. Hence the Polyurethane Rubber is most preferable for $\mathrm{V}$ Plough of a Internal scraper.

\section{CONVEYER POWER CALCULATIONS :}

\subsection{Conveyer data:}

Profile length L1 = $60.418 \mathrm{~m}$

Conveyer Total Length $\mathrm{L}=\mathrm{L} 1=60.418 \mathrm{~m}$

Lift In Length $\mathrm{H} 1=4.5 \mathrm{~m}$

Total Conveyer Lift $\mathrm{H} 1=\mathrm{H} \quad=4.5 \mathrm{~m}$

Lift $\mathrm{b} / \mathrm{w}$ Tail pulley and Drive PulleyHc $=45 \mathrm{~m}$

Conveyer Inclination In Section-I

$\delta 1=4.275$ Degrees

Maximum Slope $\delta=4.275^{\mathrm{O}}$

Type of Material to be transferred $=\mathrm{COAL}$

Rated Capacity $=3000 \mathrm{TPH}$

Design Capacity $\mathrm{C}=3600 \mathrm{TPH}$

Bulk Density $\quad \rho=800 \mathrm{Kg} / \mathrm{m} 3$

Maximum Lump Size $=300$

Filling Factor Kf $\quad=\quad 0.90$

$\begin{array}{lll}\text { Slope Factor } \mathrm{K} \quad & =98\end{array}$ 
Surcharge Angle $=\quad 20^{\mathrm{O}}$

Repose Angle $\phi \quad=\quad 37^{\circ}$

\subsection{Design parameters:}

Trough Angle $\alpha=45^{\circ}$

Belt Width $\quad \mathrm{BW}=1800 \mathrm{~mm}$

No. of Roll in Carrying Idler = 3

No. of Roll in Return Idler $\quad=\quad 2$

Cross Section Area of Load At $\quad=0.414 \mathrm{~m}^{2}$

Required Conveyer Speed $\mathrm{V}=\mathrm{C} /(3.6 \times \mathrm{At} \times \mathrm{Kf} \times \mathrm{K} \times \rho) \quad=$ $3.423 \mathrm{~m} / \mathrm{sec}$

Actual Conveyer Speed (G.R=14)

$\mathrm{V}=\pi \times$ Dh.p $\times \mathrm{N} /(60 \times \mathrm{GR})=3.608 \mathrm{~m} / \mathrm{sec}$

Mass of Material Handled $\mathrm{Wm}=(0.2778 \times \mathrm{C}) / \mathrm{V}$

$=\quad 277.14 \mathrm{Kg} / \mathrm{m} 3$

Type of Belt Duty = HEAVY

Type of Belt = $\quad \mathrm{N}-\mathrm{N}$

Minimum No. of Ply = 4

Grade $\quad=\quad$ FR (Fire Resistant $)$

Carcass Weight $=\quad 6.20 \mathrm{Kg} / \mathrm{m} 2$

Top Cover Thickness = $6 \mathrm{~mm}$

Bottom Cover Thickness $=2 \mathrm{~mm}$

Estimated Weight of belt

$\mathrm{Wb}=29.30 \mathrm{Kg} / \mathrm{m}=19.69 \mathrm{lbs} / \mathrm{ft}$

Total Weight of the system $=\quad \mathrm{Wb}+\mathrm{Wm}=306.44$

$\mathrm{Kg} / \mathrm{m}=205.92 \mathrm{lbs} / \mathrm{ft}$

No. of External Scrapers = 2

No. of Internal Scrapers $=2$

(For Contact type)

\subsection{Idler Roller Details:}

Idler Roller Diameter = 6"

Idler Class $\quad=\quad$ E6

Idler Constant $\mathrm{Ai} \quad=\quad 2.94$

Carrying Idler Spacing Si $=1.10 \mathrm{~m}$

Idler Friction Factor $\quad \mathrm{Kx}=$

$0.00068 \times(\mathrm{Wb}+\mathrm{Wm})+(\mathrm{Ai} / \mathrm{Si})=0.95$

Ambient Temperature Correction Factor $\mathrm{Kt}=$ 1.0 (From CEMA)

Skirt board friction factor $\mathrm{Cs}=$

$(2 \times \rho / 288) \times(1-\sin \Phi) /(1+\sin \Phi)=0.0862$
No of Feed point $=\quad 1$

Length of skirt board in Section-1 Lb $1=6 \mathrm{~m}$

Total Skirt Board Length $\quad$ Lb1 $=\mathrm{Lb}=6 \mathrm{~m}$

Depth of material touching skirt board

$\mathrm{Hs}=(\mathrm{BW} / 25.4) / 10=7.09 "$

co-eff. of friction $b / w$ carrying idlers and belt

$\mu=0.3$ to $0.4=0.35$

Angle of Wrap $=180^{\circ}$

Minimum Wrap Factor to prevent slip

Cwmin $=0.50$

Allowable Sag $=2 \%$

\subsection{POWER CALCULATION WITH CONTACT TYPE INTERNAL SCRAPER}

Table - 1: Conveyer Power Calculations with contact-Type internal Scraper

\begin{tabular}{|c|c|}
\hline Maximum running tension, $\mathbf{T}_{\mathbf{1}}$ (running) & $51234.12 \mathrm{~N}$ \\
\hline Slack side Tension, $\mathbf{T}_{\mathbf{2}}$ (running) & $19309.98 \mathrm{~N}$ \\
\hline Effective Tension, $\mathbf{T}_{\mathbf{e}}$ & $31924.14 \mathrm{~N}$ \\
\hline Tail Tension, $\mathbf{T}_{\mathbf{0}}$ & 24292.24 N \\
\hline Effective Tension at Starting, $\mathbf{T}_{\mathbf{e s}}$ & $38308.97 \mathrm{~N}$ \\
\hline Maximum starting tension, $\mathbf{T}_{\mathbf{1 s}}(\mathbf{s t a r t i n g})$ & $57618.95 \mathrm{~N}$ \\
\hline $\begin{array}{l}\text { Slack side Tension during starting, } \mathbf{T} \text { - } \\
\text { 2s (starting) }\end{array}$ & $19309.98 \mathrm{~N}$ \\
\hline Take-up Tension, $\mathbf{T}_{\text {tu }}$ & 24292.24 N \\
\hline
\end{tabular}

\subsubsection{Power Calculations:}

Belt Power $=\operatorname{Te} \times \mathrm{V} \times 196.8 / 33000$

$$
=154.44 \mathrm{HP}
$$

Power loss due to drive pulley

$=200 \times(\mathrm{V} \times 196.8) / 33000=4.30 \mathrm{HP}$

Absorbed power at gear box output $\operatorname{shaft}(\mathrm{Pa})$

$=$ Belt Power + power loss due to drive pulley

$$
=\quad 158.75 \mathrm{HP}=118.43 \mathrm{KW}
$$

Speed reduction loss =

Drive efficiency

$=0.94$

Therefore, 
Power Required at motor Shaft $=$ Abs power at gear box/Drive efficiency

$$
=\quad 125.87 \mathrm{KW}
$$

\subsection{POWER CALCULATION WITH ADJUSTABLE} NON-CONTACT TYPE INTERNAL SCRAPER :

Table - 2: Conveyer Power Calculations with Adjustable Type Non-contact internal Scraper

\begin{tabular}{|c|c|}
\hline Maximum running tension, $\mathbf{T}_{\mathbf{1}}$ (running) & 47968.07 N \\
\hline Slack side Tension, $\mathbf{T}_{\mathbf{2}}$ (running) & $17974.54 \mathrm{~N}$ \\
\hline Effective Tension, $\mathbf{T}_{\mathbf{e}}$ & $29993.53 \mathrm{~N}$ \\
\hline Tail Tension, $\mathbf{T}_{\mathbf{0}}$ & 20727.91 N \\
\hline Effective Tension at Starting, $\mathbf{T}_{\mathbf{e s}}$ & $35992.23 \mathrm{~N}$ \\
\hline Maximum starting tension, $\mathbf{T}_{1 \mathbf{s}}(\mathbf{s t a r t i n g})$ & $53966.77 \mathrm{~N}$ \\
\hline $\begin{array}{l}\text { Slack side Tension during starting, } \\
\mathbf{T}_{\mathbf{2 s}} \text { (starting) }\end{array}$ & $17974.54 \mathrm{~N}$ \\
\hline Take-up Tension, $\mathbf{T}_{\text {tu }}$ & 20727.91 N \\
\hline
\end{tabular}

\subsubsection{Power Calculations:}

Belt Power $=\mathrm{Te} \times \mathrm{V} \times 196.8 / 33000$

$$
=145.10 \mathrm{HP}
$$

Power loss due to drive pulley

$=200 \times(\mathrm{V} \times 196.8) / 33000=\mathbf{4 . 3 0} \mathbf{~ H P}$

Absorbed power at gear box output $\operatorname{shaft}(\mathrm{Pa})$

$=$ Belt Power + power loss due to drive pulley

$=149.41 \mathrm{HP}=111.46 \mathrm{KW}$

$\begin{array}{lll}\text { Speed reduction loss } & = & (6 \%) \\ \text { Drive efficiency } & = & 0.94\end{array}$

Therefore,

Power Required at motor Shaft $=$ Abs power at gear box/Drive efficiency

\section{$=\quad 118.46 \mathrm{KW}$}

Power savings using adjustable internal scrapper in non contact position,

$=125.87-118.46=\mathbf{7 . 4 1 K W}$

Power savings per year using adjustable internal scrapper in non contact position,

$=7.41 \times 16 \times 300=35568 \mathrm{Kw}$ (considering 2 shift operation and 300 days dry material)

\section{CONCLUSIONS AND FUTURE SCOPE :}

Power savings using adjustable internal scrapper in non contact position comes to $7.41 \mathrm{KW}$. Power savings per year using adjustable internal scrapper in non contact position is $35568 \mathrm{KW}$ (considering 2 shift operation and 300 days dry material). When the adjustable Internal scraper is used in non-contact position the belt life will also improve, By development of adjustable type internal scrapper 3-D part model it is understood that the production cost of adjustable type internal scrapper shall not overweigh the power savings it does, As per the results of static analysis Polyurethane is preferable material for V-plough

By using wetness detectors and actuators the adjustment of internal scrappers position may be automated Friction less materials can be used for v-plough to save more power in rainy season

\section{REFERENCES}

[1] PAWAR JYOTSNA, D.D.DATE, PRATIK SATAV, International Journal of Mechanical And Production Engineering, ISSN: 2320-2092, Volume- 2, Issue-8, Aug.-2014

[2] Seema S. Vanaman, Pravin A. Mane, International Journal of Engineering Research and Applications (IJERA), ISSN: 2248-9622, Vol. 2, Issue 3, May-Jun 2012, pp.2162-2167

[3] R.K.Bhoyar, Dr. C.C.Handa, International Journal of Engineering Trends and Technology (IJETT) - Volume 4 Issue 10 - Oct 2013

[4] Hitesh J Soni, Mr. Ronak R Patel, IJSRD - International Journal for Scientific Research \& Development| Vol. 2, Issue 04, 2014 | ISSN (online): 2321-0613

[5] Belt Conveyers for bulk materials $-5^{\text {th }}$ Edition CEMA

\section{BIOGRAPHIES}

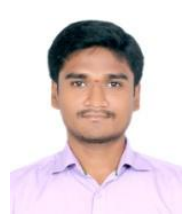

A. L. N. Arun kumar is working as a assistant professor in the department of Mechanical Engg., C.V.R College Of Engineering

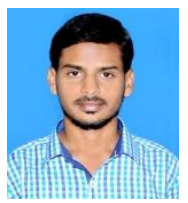

S. MD. Jameel basha is working as a assistant professor in the department of Mechanical Engg., N.I.ST.,

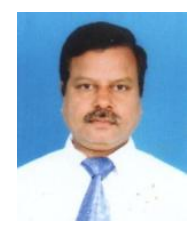

Dr. M. Sreenivasulu, is working as a professor in the department of Mechanical Engg., N.B.K.R.I.S.T., 